\title{
FLORISTIC COMPOSITION AND VEGETATION ANALYSIS OF A DELTAIC STRIP ON THE EGYPTIAN MEDITERRANEAN COAST
}

\author{
GALAL, T. M. ${ }^{1 *}-$ Ali, E. F. ${ }^{1}-$ AL-YASI, H. M. ${ }^{1}-$ SAIF, T. ${ }^{1}-$ HASSAN, L. M. ${ }^{2}$ \\ ${ }^{1}$ Biology Department, Faculty of Science, Taif University, P.O. Box 11099, Taif 21944, Saudi \\ Arabia \\ ${ }^{2}$ Botany and Microbiology Department, Faculty of Science, Helwan University, Cairo 11790, \\ Egypt \\ *Corresponding author \\ e-mail: tarekhelwan@yahoo.com; phone: +966-57-015-9791 \\ (Received $5^{\text {th }}$ Feb 2021; accepted $9^{\text {th }}$ Apr 2021)
}

\begin{abstract}
Floristic features and vegetation of an Egyptian Deltaic Mediterranean coastal strip were assessed in terms of species composition, habitat characterization, vegetation analysis, and the economic and ecological importance of the recorded species. Four different habitats (salt marshes, sand formations, sand bars, and tidal flats) were surveyed during spring season 2018 through 25 stands $(10 \times 10 \mathrm{~m})$ representing the different vegetation physiognomy and habitat types of the study area. Thirty-two species including 21 perennials and 11 annuals belonging to 14 families were recorded with a dominance of Asteraceae. Therophytes predominated the other life forms and biregional taxa dominated over the other phytogeographical elements. Five common plant communities were identified after the application of TWINSPAN: Arthrocnemum macrostachyum-Sarcocornia fruticose, Halocnemum strobilaceum, Zygophyllum aegyptium-Ephedra alata, Phragmites australis, and Sarcocornia fruticosa- Tamarix nilotica group. Twenty-seven species have medicinal, 26 grazing, 9 fuel and 8 human food uses. On the other hand, 16 species are sand controller and 11 are ruderals. The salt marshes had the highest species diversity, while the tidal flats had the lowest. The present work documented the plant diversity in the study area, which is proposed for urbanization and consequently habitat destruction and biodiversity loss. Keywords: habitats, sand formations, salt marshes, Nile Delta, flora, multivariate analysis
\end{abstract}

\section{Introduction}

The Mediterranean coastal ecosystems are affected by various climates such as hyper-arid, arid, semi-humid and humid (Galal, 2005). They are subjected to extreme conditions and increasing stress due to human impacts such as land use, desertification, and climatic changes (Naveh and Dan, 1973). The Egyptian Mediterranean coastal area provides an evidence of anthropogenic disturbances, which led to habitat loss and habitat fragmentation resulting in diminishing the germplasm reservoir (El-Sadek and Ayyad, 2000). The Mediterranean coast of the Nile Delta is a narrow belt that was greatly affected by the sea and is characterized by villages and summer resorts (Zahran and Willis, 2009). Along the deltaic shoreline, there are sand dunes associated with the eastern banks of the past and present Nile branches (Galal and Fawzy, 2007).

Plant community plays a crucial role in maintaining biodiversity and conserving the environment and consequently sustainable management (Kandi et al., 2011; Shehata and Galal, 2015). Vegetation has been widely used to assess water quality and habitat characterization, in addition to predicting the properties of the neighboring communities (Appelgren and Mattila, 2005). Variation in the natural ecosystem components such as plant communities has led to a gradual variation in the structure, and composition of these communities. Therefore, studying the impact of environmental variables on the 
classification and structure of plant communities is of great importance (Jafari et al., 2003). Zegeye et al. (2006) reported that the inter-relations between community type and soil characteristics resulted in variations of species composition, vegetation, and plant community distribution (Galal et al., 2012). The floristic and plant ecological studies of the Mediterranean deltaic Coast were the main important research topic for several years (e.g., Mashaly, 1987; Khedr, 1989, 1997; Serag, 1991; Shaltout et al., 1995; Khedr and El-Demerdash, 1997; Galal et al., 2012).

The vegetation along the delta coast is characterized by several mechanically distinct and dynamic habitats, which are subjected to destruction by catastrophic changes of storms and floods, which can hamper habitat restoration due to the destruction of parent plants and their seed banks (Khedr and El-Demerdash, 1997). Multivariate analysis of vegetation including classification and ordination techniques was used to assess the ecological relationships between plant communities and their environment (Zhang and Zhang, 2000). In addition, the floristic studies are not only important in order to identify plant species in a certain area, but because plant species are socio-economically significant, where they are utilized as food, shelter, medicine and are extremely important for all living organisms in that area (Shehata and Galal, 2015).

The Egyptian Mediterranean coast contains the most valuable rangeland in the country; however, the uncontrolled cutting, grazing, and farming have induced serious destruction of its natural ecosystems (Shaltout et al., 1995). Due to increasing the Egyptian population, the Deltaic coast is subjected to increased anthropogenic disturbances (Imam and Kosinova, 1972). Moreover, the study area includes characteristic habitats such as salt marshes, tidal flats, sand bars and sand formations (sand hillocks, sand sheets, and baby sand dunes). The study was carried on a proposed area for urban projects, and thus the habitats in this area is subjected to destruction and loss of their biodiversity. Therefore, the main objectives of the present work are the description and analysis of the floristic features and vegetation types of this strip on the deltaic Mediterranean coast in terms of species composition, habitat characterization and plant diversity. In addition, it aims at identifying the goods and services provided by the recorded species. This study will document the plant diversity in such important area, which may be subjected to habitat destruction and biodiversity loss.

\section{Materials and methods}

\section{Study area and data collection}

The area of the Nile Delta approximates $22,000 \mathrm{~km}^{2}$ comprising about $63 \%$ of the Egyptian fertile lands (Abu Al-Izz, 1971). Due to the agricultural activities along southlands of years, all soils except those of the northern coast, are man-made and are considered as anthropic variants of the Fluvisols and Gleysols (El-Bayomi, 1999; Galal et al., 2012). The study area $\left(31^{\circ} 26^{\prime}-31^{\circ} 27^{\prime} \mathrm{N}\right.$ and $\left.30^{\circ} 28^{\prime}-30^{\circ} 29^{\prime} \mathrm{E}\right)$ was located at the coastal area of the Nile Delta (Fig. 1), which lies in the arid zone (Shehata and Galal, 2015). According to the map of UNESCO (1977) for arid regions, the northern Deltaic part belongs to the Mediterranean arid region. Climate is characterized by warm summer $\left(20\right.$ to $\left.30{ }^{\circ} \mathrm{C}\right)$ and mild winter $\left(10\right.$ to $\left.20{ }^{\circ} \mathrm{C}\right)$. The aridity index, calculated as $\mathrm{P} / \mathrm{PET}$, where $\mathrm{P}$ and PET are the annual precipitation and potential evapo-transpiration, respectively, ranges between 0.03 and 0.20 (Galal and Fawzy, 2007).

Four different habitats (salt marshes, sand formations, sand bars, and tidal flats; see Fig. 2) were surveyed during spring season (March-May) 2018 through 25 stands (10 $\times$ 
$10 \mathrm{~m}$ ) representing the apparent variation in the vegetation physiognomy in about $1 \mathrm{~km}^{2}$ estimated area. Stands were distributed as six in each of the four habitats except sand formations (7 stands). At each stand, a list of species, the dominant species and visual estimate of the total cover and the cover of each species (\%) were recorded. Identification and nomenclature of the recorded species were carried out according to Täckholm (1974) and Boulos (1999, 2000, 2002, 2005, 2009). The life form spectra of the recorded species were determined according to Raunkiaer scheme (Raunkiaer, 1937), while the global phytogeographical distribution was identified from Täckholm (1974), Zohary (1973) and Boulos (1999, 2000, 2002, 2005, 2009).

The environmental goods and economic services of the recorded species were determined based on-site observations, collected information from inhabitants and from the literature (e.g., Täckholm, 1974; El-Kady, 1980; Zohary, 1966, 1972; FeinbrunDothan, 1978, 1986; Danin, 1983; Boulos, 1983, 1989; Belal and Springuel, 1996; Shaltout, 1997). Economic services were classified into five categories: grazing, fuel, medicinal, edible, and other uses including furniture, making mats, chairs, and ornamental). The aspects of environmental importance include segetals, ruderals, sand controllers (i.e., sand binder, hummock, and wind breaks), bank retainers, shaders, parasites, poisoners, invaders, weed controllers, nitrogen fixers and water purificators.

\section{Data analysis}

Multivariate analysis of the vegetation using Two-way indicator species analysis (TWINSPAN) and Detrended Correspondence Analysis (DCA) as classification and ordination techniques, respectively were applied to the matrix of 32 species in 25 stands in the Deltaic coast (Hill, 1979a, b). Plant diversity was assessed by determining species richness for each vegetation group resulted from the multivariate analysis, which was calculated as the average number of species per sampling plot. Shannon-Weaver index denoting the equitability or relative evenness was expressed as:

$$
\hat{\mathrm{H}}=-\Sigma_{\mathrm{S}_{\mathrm{i}}}=1 \mathrm{P}_{\mathrm{i}}\left(\log \mathrm{P}_{\mathrm{i}}\right)
$$

where $\mathrm{S}$ is the total number of species and Pi is the relative cover of the $\mathrm{i}^{\text {th }}$ species. In addition, Simpson index was used to estimate the relative concentration of dominance, which is calculated as:

$$
\mathrm{D}=1 / \mathrm{C} \text { and } \mathrm{C}=\Sigma \mathrm{si}=1(\mathrm{Pi})^{2}
$$

where $\mathrm{S}$ is the total number of species and $\mathrm{Pi}$ is the relative importance value (relative cover) of species (Magurran, 1988).

\section{Results}

Thirty-two species including 21 perennials and 11 annuals related to 14 families were recorded in the different habitats in the area under investigation (Table 1). Asteraceae family was the dominant ( 8 species), followed by Chenopodiaceae (6 species) and Poaceae (5 species). Eighteen species were recorded as natural plants (e.g., Ephedra alata, Zygophyllum aegyptium and Echinops spinosus), while 13 species were terrestrial weeds (e.g., Lotus glaber, Senecio vulgaris and Soncuhs oleraceous), and one wetland weed (Phragmites australis). The life forms of the recorded species showed the 
predominance of therophytes (34\% of the total species) over chamaephytes $(22 \%)$, geophytes-helophytes (19\%), hemicryptophytes (13\%), phanerophytes (9\%) and parasites (3\%) (Fig. 3). The chorological analysis of the recorded species showed that the biregional taxa $(41 \%)$ dominated over the pluriregional $(31 \%)$ and monoregional (16\%), while cosmopolitan elements were represented by $12 \%$ (Fig. 4).

\section{Habitat characterization}

The main recognized habitats in the study area are salt marshes, tidal flats, sand bars, and sand formations (Table 1). The characteristics of these habitats are described as follows:

\section{Salt marshes (6 stands)}

The coastal salt marshes are lowlands covered with water during the tide of the Mediterranean Sea with high salinity associated with high evaporation rate. They were covered with halophytes, which are salt tolerant plants of high potential for collecting and fixing soil deposits. Their clay deposits vary between 60 and $80 \%$. Sixteen species were recorded along this habitat, the dominant of which are: Arthrocnemum macrostachyum, Halocnemum strobilaceum, Sarcocornia fruticosa and Zygophyllum aegyptium, while the common associated species are: Ephedra alata, Senecio glaucus subsp. coronopifolius and Reichardia tingitana. The species diversity in this habitat (species richness) was 5.3 species/stand.

\section{Tidal flats (6 stands)}

These flats extend along the shores, and mainly they are submerged by the sea water during the tide, but during the ebb-tide water retreats again. They were devoid of plants as their surface was composed of homogeneous soil granules. Tidal flats are consisted of friable sands produced due to the erosion of the shore through the effect of waves. Thirteen species were recorded in these sand formations, the dominant of which: $A$. macrostachyum, S. glaucus subsp. coronopifolius and $Z$. aegyptium. Cistanche phelypaea, Rumex pictus and Cakile maritima are common associated species. The species diversity in this habitat (species richness) was 3.4 species/stand.

\section{Sand bars (6 stands)}

The study site contains a small sand bar (dunes) 2-3 $\mathrm{m}$ high. The merging of hillocks led to the formation of large dunes covered with dense vegetation. These dunes of the marine bar were affected by sand deposition. Nine species were recorded along this habitat, of them: Ephedra alata, Salsola kali, Z. aegyptium and A. macrostachyum. The species diversity in this habitat was 3.9 species/stand.

\section{Sand formations (7 stands)}

The marine bar of the study area was covered with three types of sand formations: sand sheets (or flats), baby sand dunes and hillocks, which were covered by some herbs and shrubs like Tamarix nilotica, which help in fixing these hillocks. Twenty-four species were recorded in the different sand formations of the study area, which includes: $Z$. aegyptium, $T$. nilotica and Imperata cylindrica. The species diversity in this habitat was 3.4 species/stand. 
Table 1. Floristic categories and life forms of the species recorded in the study area

\begin{tabular}{|c|c|c|c|c|c|c|c|c|}
\hline \multirow{2}{*}{ Species } & \multirow{2}{*}{ State } & \multirow{2}{*}{ Habit } & \multirow{2}{*}{$\begin{array}{l}\text { Life } \\
\text { form }\end{array}$} & \multirow{2}{*}{ Floristic category } & \multicolumn{4}{|c|}{ Habitat } \\
\hline & & & & & SM & SB & TF & SF \\
\hline Ephedraceae & & & & & & & & \\
\hline Ephedra alata Decne. & NP & Perennial & $\mathrm{Ch}$ & SA-AR & 1 & 1 & 1 & 1 \\
\hline Polygonaceae & & & & & & & & \\
\hline Rumex pictus Forssk. & NP & Annual & Th & $\mathrm{ME}+\mathrm{SA}-\mathrm{AR}$ & & & 1 & \\
\hline Chenopodiaceae & & & & & & & & \\
\hline Anabasis articulata (Forssk.) Moq. & NP & Perennial & $\mathrm{Ch}$ & SA-AR & 1 & & & \\
\hline Arthrocnemum macrostachyum (Moric.) K. Koch & NP & Perennial & $\mathrm{Ch}$ & $\mathrm{ME}+\mathrm{SA}-\mathrm{AR}$ & 1 & 1 & 1 & 1 \\
\hline Bassia indica (Wieght) A. J. Scott & TW & Annual & Th & $\mathrm{IR}-\mathrm{TR}+\mathrm{S}-\mathrm{Z}$ & & & & 1 \\
\hline Halocnemum strobilaceum (Pall.) M. Bieb. & NP & Perennial & $\mathrm{Ch}$ & $\mathrm{ME}+\mathrm{SA}-\mathrm{AR}+\mathrm{IR}-\mathrm{TR}$ & 1 & & 1 & \\
\hline Salsola kali L. & NP & Annual & Th & COSM & 1 & 1 & & \\
\hline $\begin{array}{c}\text { Sarcocornia fruticosa (L.) A. J. Scott. } \\
\text { Brassicaceae }\end{array}$ & NP & Perennial & $\mathrm{Ch}$ & SA-AR & 1 & 1 & 1 & 1 \\
\hline $\begin{array}{c}\text { Cakile maritima Scop. } \\
\text { Fabaceae }\end{array}$ & NP & Annual & Th & $\mathrm{ME}+\mathrm{IR}-\mathrm{TR}$ & & & 1 & \\
\hline $\begin{array}{c}\text { Lotus glaber Mill. } \\
\text { Zygophyllaceae }\end{array}$ & TW & Perennial & $\mathrm{H}$ & ME+ER-SR+IR-TR & 1 & & & 1 \\
\hline $\begin{array}{c}\text { Zygophyllum aegyptium L.f. } \\
\text { Tamaricaceae }\end{array}$ & NP & Perennial & $\mathrm{Ch}$ & $\mathrm{ME}+\mathrm{SA}-\mathrm{AR}$ & 1 & 1 & 1 & 1 \\
\hline $\begin{array}{c}\text { Tamarix nilotica (Ehrenb.) Bunge } \\
\text { Asclepiadaceae }\end{array}$ & NP & Perennial & $\mathrm{Ph}$ & $\mathrm{SA}-\mathrm{AR}+\mathrm{S}-\mathrm{Z}$ & 1 & & 1 & 1 \\
\hline $\begin{array}{c}\text { Cynanchum acutum } \mathrm{L} . \\
\text { Orobanchaceae }\end{array}$ & TW & Perennial & $\mathrm{Ph}$ & ME+IR-TR & & & & 1 \\
\hline $\begin{array}{c}\text { Cistanche phelypaea (L.) Cout. } \\
\text { Asteraceae }\end{array}$ & NP & Perennial & $\mathrm{P}$ & $\mathrm{ME}+\mathrm{SA}-\mathrm{AR}$ & & & 1 & 1 \\
\hline Atractylis carduus (Forssk.) C. Chr. & NP & Perennial & $\mathrm{Ch}$ & SA-AR & 1 & & & 1 \\
\hline Echinops spinosus L. & NP & Perennial & $\mathrm{H}$ & $\mathrm{ME}+\mathrm{SA}-\mathrm{AR}$ & & & & 1 \\
\hline Iflago spicata (Forssk.) Sch.Bip. & NP & Annual & Th & $\mathrm{ME}+\mathrm{SA}-\mathrm{AR}$ & & 1 & & \\
\hline Launaea fragilis (Asso) Pau & NP & Perennial & $\mathrm{H}$ & SA-AR & 1 & & & \\
\hline Reichardia tingitana (L.) Roth & NP & Annual & $\mathrm{Th}$ & IR-TR+SA-AR & 1 & & & 1 \\
\hline Senecio glaucus subsp. coronopifolius (Maire) C. Alexander & TW & Annual & Th & $\mathrm{ME}+\mathrm{SA}-\mathrm{AR}+\mathrm{IR}-\mathrm{TR}$ & 1 & 1 & 1 & 1 \\
\hline Senecio vulgaris L. & TW & Annual & Th & ME+ER-SR+IR-TR & & 1 & & \\
\hline Silybum marianum (L.) Gaertn. & TW & Perennial & $\mathrm{H}$ & ME+ER-SR+IR-TR & & & & 1 \\
\hline $\begin{array}{c}\text { Soncuhs oleraceous L. } \\
\text { Juncaceae }\end{array}$ & TW & Annual & Th & COSM & 1 & & & 1 \\
\hline Juncus acutus L. & TW & Perennial & GH & $\mathrm{ME}+\mathrm{ER}-\mathrm{SR}+\mathrm{IR}-\mathrm{TR}$ & & & & 1 \\
\hline $\begin{array}{c}\text { Juncus rigidus Desf. } \\
\text { Poaceae }\end{array}$ & TW & Perennial & $\mathrm{GH}$ & $\mathrm{ME}+\mathrm{SA}-\mathrm{AR}+\mathrm{IR}-\mathrm{TR}$ & & & & 1 \\
\hline Cutandia memphitica (Spreng.) K. Richt. & TW & Annual & Th & $\mathrm{ME}+\mathrm{SA}-\mathrm{AR}+\mathrm{IR}-\mathrm{TR}$ & 1 & & 1 & 1 \\
\hline Cynodon dactylon (L.) Pers. & TW & Perennial & $\mathrm{GH}$ & COSM & & & & 1 \\
\hline Imperata cylindrica (L.) Raeusch. & TW & Perennial & $\mathrm{GH}$ & $\mathrm{ME}+\mathrm{SA}-\mathrm{AR}+\mathrm{IR}-\mathrm{TR}$ & & & & 1 \\
\hline Phragmites australis (Cav.) Trin. ex Steud & AW & Perennial & GH & COSM & 1 & 1 & 1 & 1 \\
\hline Schismus barbatus (L.) Thell. & NP & Annual & $\mathrm{Th}$ & $\mathrm{ME}+\mathrm{SA}-\mathrm{AR}+\mathrm{IR}-\mathrm{TR}$ & & & 1 & 1 \\
\hline $\begin{array}{c}\text { Palmae } \\
\text { Phoenix dactylifera } \mathrm{L} . \\
\text { Cyperaceae }\end{array}$ & NP & Perennial & $\mathrm{Ph}$ & $\mathrm{SA}-\mathrm{AR}+\mathrm{S}-\mathrm{Z}$ & & & & 1 \\
\hline Cyperus capitatus Vand. & TW & Perennial & $\mathrm{GH}$ & $\mathrm{ME}+\mathrm{GC}$ & & & & 1 \\
\hline
\end{tabular}

$\mathrm{Ph}$ : phanerophytes, $\mathrm{Ch}$ : chamaephytes, H: hemicryptophytes, GH: geophytes-helophytes, Th: therophytes and P: parasites. The floristic categories are ME: Mediterranean, COSM: Cosmopolitan, SA-AR: Saharo-Arabian, SU-ZA: Sudano-Zambezian, ER-SR: Euro-Sibarian, IR-TR: Irano-Turanian, SM: salt marshes, SB: sand bar, TF: tidal flats, SF: sand formation, NP: natural plants, TW: terrestrial weeds and AW: wetland weed 


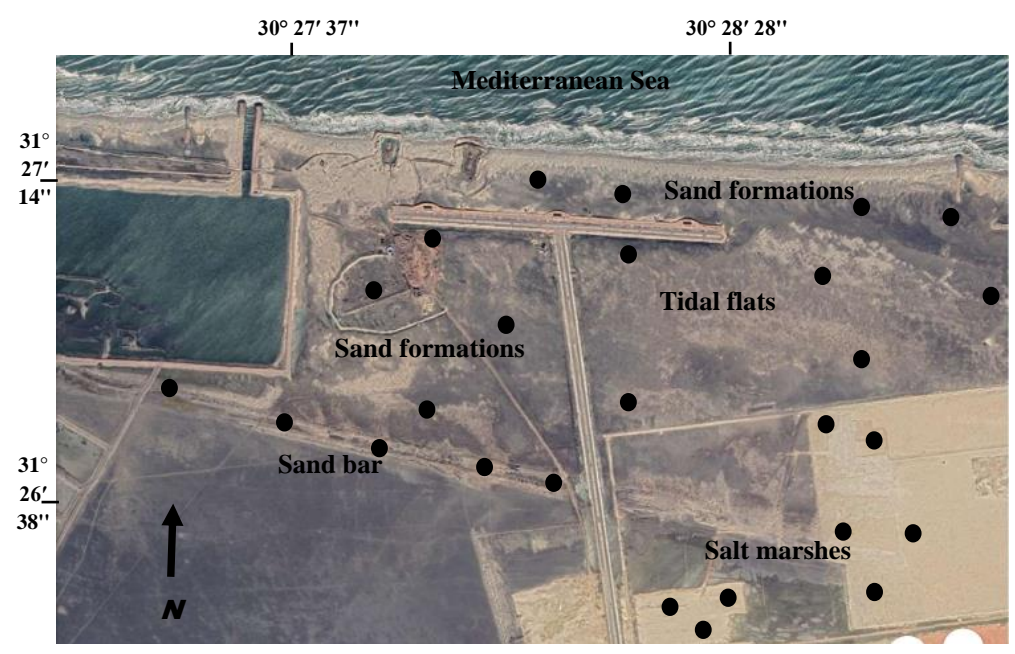

Figure 1. Location map of the study area showing the sampled sites $\left(31^{\circ} 26^{\prime}-31^{\circ} 27^{\prime} \mathrm{N}\right.$ and $30^{\circ} 28^{\prime}-30^{\circ} 29^{\prime}$ E). Source: Google earth on 19 April 2018

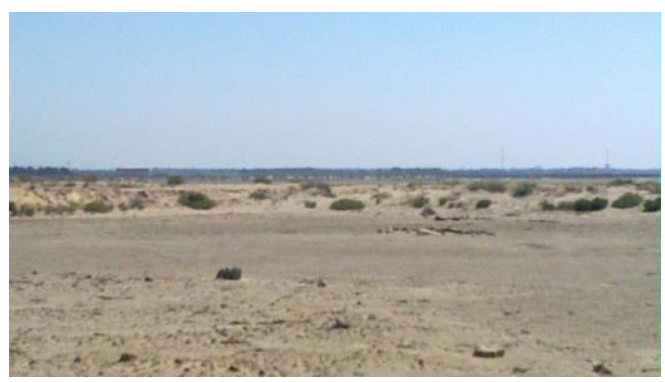

$\mathbf{a}$

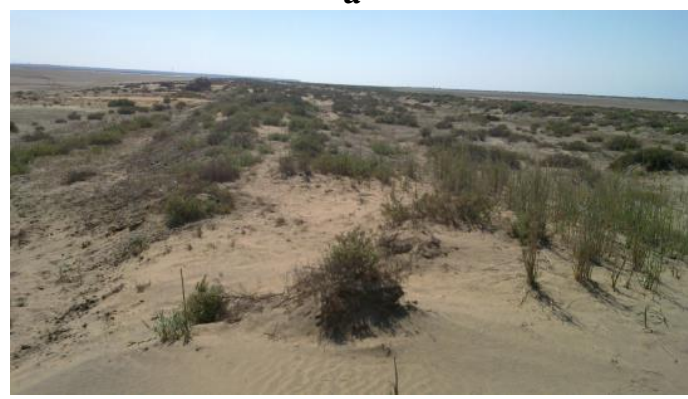

c

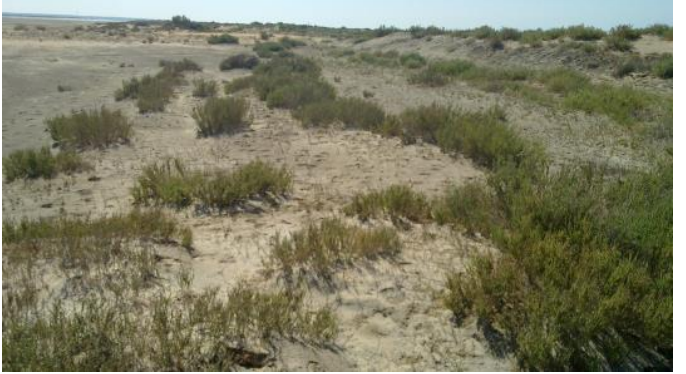

b

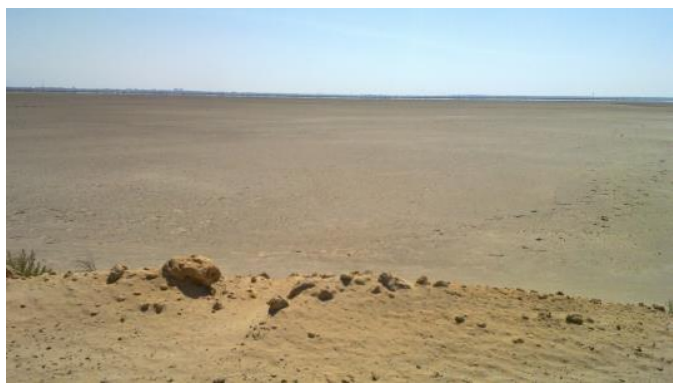

d

Figure 2. (a) Vegetated sand bar, (b) salt marshes with halophytes, (c) sand formations with dense vegetation, $(d)$ tidal flats with very scares vegetation

\section{Environmental and economic importance}

Twenty-nine species in the study area have at least one aspect of the environmental importance (Table 2). Six species have three environmental importance, of which: $T$. nilotica (shaders, ruderals, and sand controllers), A. macrostachyum (bank retainer, weed controller and sand controller) and $P$. australis (ruderal, invader and water purificator). A total of 11 species have two environmental importance such as Anabasis articulata (shader and sand controller) and $C$. phelypaea (sand controller and parasite). A total of 12 species have only one importance such as Juncus rigidus (ruderal) and $Z$. aegyptium (sand controller). 
Table 2. Environmental and economic values of the recorded species in the Deltaic strip of the study area

\begin{tabular}{|c|c|c|c|c|c|c|c|c|c|c|c|c|c|c|c|c|c|c|}
\hline \multirow[b]{2}{*}{ Species } & \multicolumn{11}{|c|}{ Environmental importance } & \multicolumn{7}{|c|}{ Economic importance } \\
\hline & $\bar{s}$ & ๘ & $\bar{z}$ & $\frac{3}{6}$ & $\Xi$ & $\ddot{z}$ & $\ddot{n}$ & $\hat{z}^{2}$ & $\tilde{E}$ & 5 & 吾 & 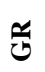 & 穴 & $\sum_{\Sigma}^{5}$ & 䛼 & $F$ & '̄o & 조 \\
\hline Anabasis articulata & & + & & & & & + & & & & 2 & + & + & + & & & & 3 \\
\hline $\begin{array}{l}\text { Arthrocnemum } \\
\text { macrostachyum }\end{array}$ & + & & & & & + & + & & & & 3 & + & + & + & & & & 3 \\
\hline Atractylis carduus & & & & & & & + & & & + & 2 & + & & + & & & & 2 \\
\hline Bassia indica & & & + & & & & & & & & 1 & + & + & + & & & & 3 \\
\hline Cakile maritima & & + & & & & & + & & & + & 3 & + & & + & & & + & 3 \\
\hline Cistanche phelypaea & & & & & & & + & & + & & 2 & & & + & & & & 1 \\
\hline Cutandia memphitica & & & & & & & + & & & & 1 & + & & & & & & 1 \\
\hline Cynanchum acutum & & & + & & & & & & & & 1 & & & & & & & \\
\hline Cynodon dactylon & & & & + & & & + & & & & 2 & + & + & + & & & & 3 \\
\hline Echinops spinosus & & & & & & & + & & & + & 2 & + & + & + & + & & & 4 \\
\hline Ephedra alata & & + & & & & & + & & & + & 3 & & & + & & & & 1 \\
\hline Halocnemum strobilaceum & + & & & & & & + & & & & 2 & + & & + & & & & 2 \\
\hline Iflago spicata & & & & & & & & & & + & 1 & + & & + & & & & 2 \\
\hline Imperata cylindrica & + & & + & & & + & & & & & 3 & + & & + & & & + & 3 \\
\hline Juncus acutus & & & + & & & & + & & & & 2 & + & & + & & & + & 3 \\
\hline Juncus rigidus & & & + & & & & & & & & 1 & + & & + & & & + & 3 \\
\hline Launaea fragilis & & & & & & & & & & & & + & & + & & & & 2 \\
\hline Lotus glaber & & & + & & & & & & & & 1 & + & & + & & & & 2 \\
\hline Phoenix dactylifera & & & & & & & & & & & & + & + & + & + & + & + & 6 \\
\hline Phragmites australis & & & + & & + & & & + & & & 3 & + & + & + & + & & + & 5 \\
\hline Reichardia tingitana & & & & & & & + & & & + & 2 & + & & + & & & & 2 \\
\hline Rumex pictus & & & + & & & & & & & & 1 & + & & + & + & & & 3 \\
\hline Salsola kali & & & + & & & & & & & & 1 & & & + & + & & + & 3 \\
\hline Sarcocornia fruticosa & & & & & & & + & & & + & 2 & + & + & + & & & & 3 \\
\hline Schismus barbatus & & & & + & & & & & & & 1 & + & & + & & & & 2 \\
\hline $\begin{array}{l}\text { Senecio glaucus subsp. } \\
\quad \text { coronopifolius }\end{array}$ & & & & + & & & & & & & 1 & & & & + & & & 1 \\
\hline Senecio vulgaris & & & & & & & + & & & + & 2 & + & & + & & & & 2 \\
\hline Silybum marianum & & & + & & & + & & & & & 2 & + & & + & + & & & 3 \\
\hline Soncuhs oleraceous & & & & + & & & & & & & 1 & + & & & + & & & 2 \\
\hline Tamarix nilotica & & + & + & & & & + & & & & 3 & + & + & + & & & & 3 \\
\hline Zygophyllum aegyptium & & & & & & & + & & & & 1 & + & & + & & & + & 3 \\
\hline Total & 3 & 3 & 11 & 4 & 1 & 3 & 16 & 1 & 1 & 8 & & 26 & 9 & 27 & 8 & 1 & 8 & \\
\hline
\end{tabular}

Br: bank retainer, FU: fuel, GR: grazing, HF: human food, In: water invaders, ME: medicinal use, Nf: nitrogen fixers, OT: other uses, Pa: parasites, Po: poisoners, Ru: ruderals, Sc: sand controllers, Sh: shaders, Sw: segetal weed, TI: timber Wc: weed controllers, and Wp: water purificators. EI: economic index (out of 6)

Thirty species have at least one potential or actual economic uses (Table 2). Phoenix dactylifera has six uses and Phragmites australis has five uses. Echinops spinosus has four uses. A total of 14 species have three uses such as Silybum marianum (grazing, medicinal and human food uses) and A. macrostachyum and $S$. fruticosa (grazing, fuel and medicinal uses). A total of 9 species have two uses such as $H$. strobilaceum and $R$. tingitana (grazing and medicinal uses) and Sonchus oleraceous (grazing and human food uses). Four species have only on use such as Cutandia memphitica (grazing), C. phelypaea (medicinal use) S. glaucus subsp. coronopifolius (human food). 


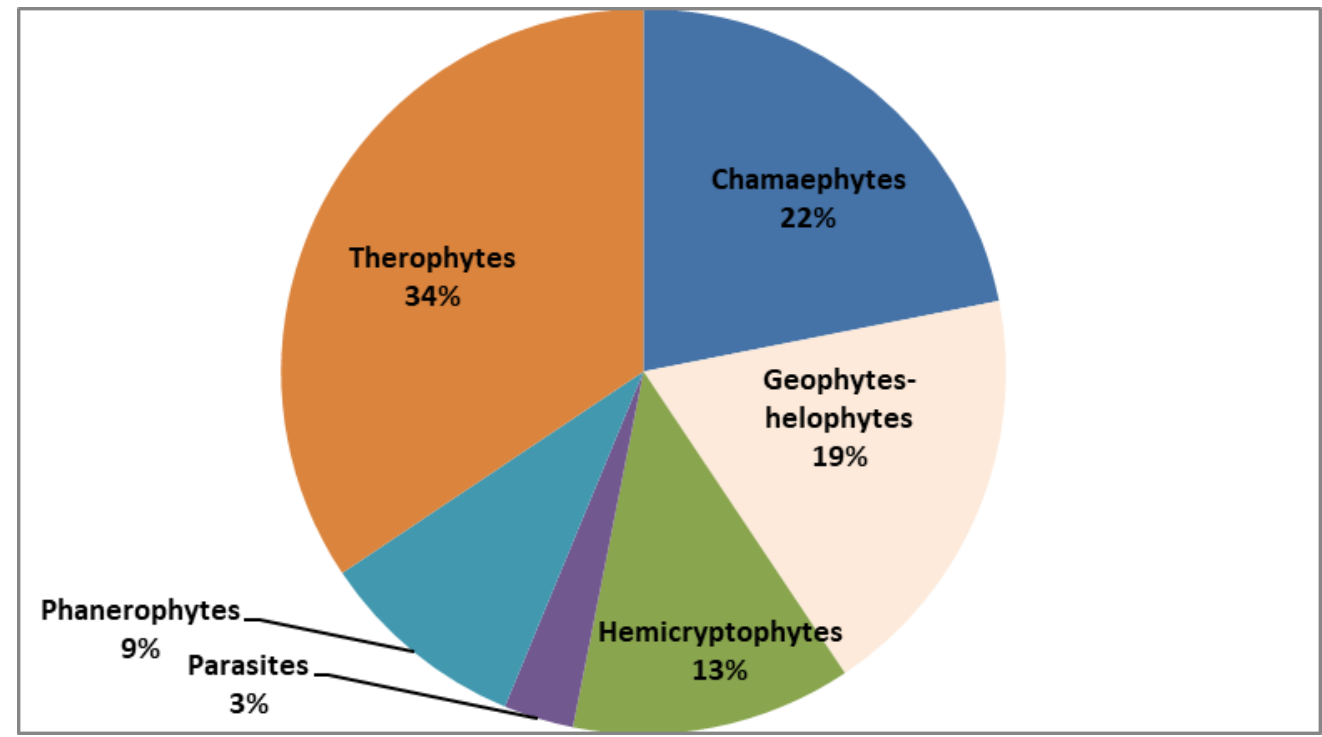

Figure 3. Life forms of the recorded species in the Deltaic coastal strip under study

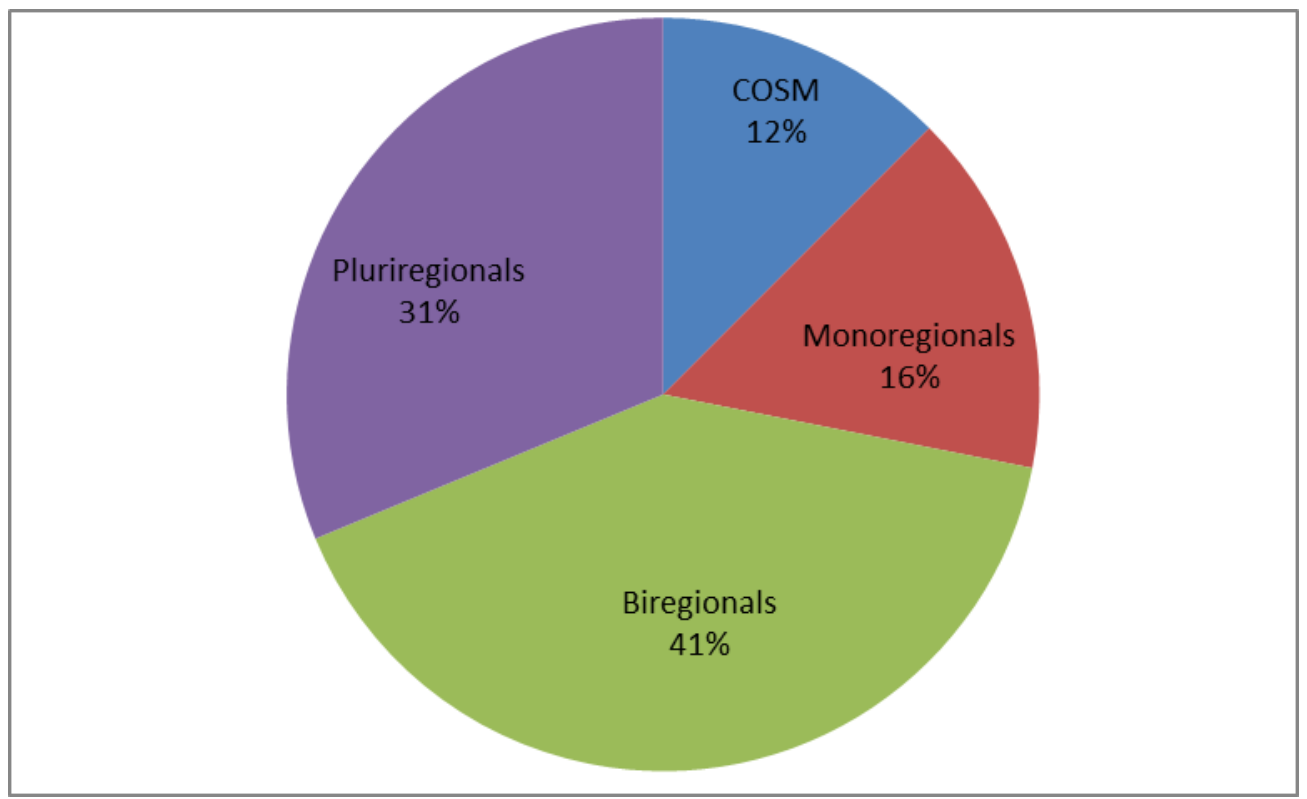

Figure 4. Chorological elements of the recorded species in the Deltaic coastal strip under study

\section{Vegetation analysis}

The application of multivariate analysis on the cover of 32 species in 25 sampled stands produced five vegetation groups (Figs. 5 and 6). These vegetation groups are named based on the first and occasionally the second dominant species (Table 3):

a. Sarcocornia fruticosa- Tamarix nilotica group: This group included only two species, which dominated the sand formations.

b. Arthrocnemum macrostachyum-Zygophyllum aegyptium group: This group comprised seven species recorded in three stands. It characterizes the salt 
marsh habitat. Ephedra alata, Phragmites australis and Senecio glaucus subsp. coronopifolius are the common associated species.

c. Halocnemum strobilaceum group: Ten species recorded in six stands represented this group. It was commonly represented in the sand formations habitat. The most common species are: Senecio glaucus subsp. coronopifolius, Salsola kali, Rumex pictus and Cakile maritima.

d. Zygophyllum aegyptium-Ephedra alata group: This group was represented by 17 species monitored in 13 stands. It was dominant in the salt marsh and sand bar habitats. The common associated species are: Senecio glaucus subsp. coronopifolius, Arthrocnemum macrostachyum, Salsola kali and Phragmites australis.

e. E. Phragmites australis group: Five species constituted this group and are recorded in two stands, which dominated the sand bar habitat in the study site. Salsola kali, Sarcocornia fruticosa, Senecio glaucus subsp. coronopifolius and Zygophyllum aegyptium were the common associates.

Table 3. Presence percentage of the recorded species in the 5 vegetation groups produced from TWINSPAN

\begin{tabular}{|c|c|c|c|c|c|}
\hline Vegetation group & $\mathbf{A}$ & B & $\mathbf{C}$ & D & $\mathbf{E}$ \\
\hline Anabasis articulata & & & & 7.7 & \\
\hline Arthrocnemum macrostachyum & & 66.6 & 1 & 53.8 & \\
\hline Atractylis carduus & & & & 7.7 & \\
\hline Cakile maritima & & & 16.7 & & \\
\hline Cistanche phelypaea & & & & 7.7 & \\
\hline Cutandia dichotoma & & & 16.7 & & \\
\hline Ephedra alata & & 33.3 & & 84.6 & \\
\hline Halocnemum strobilaceum & & 1 & 66.7 & 7.7 & \\
\hline Iflago spicata & & & & 7.7 & \\
\hline Launaea fragilis & & & & 23.1 & \\
\hline Lotus glaber & & & & 7.7 & \\
\hline Senecio vulgaris & & & & 7.7 & \\
\hline Phragmites australis & & 33.3 & & 23.1 & 100 \\
\hline Reichardia tingitana & & & & 7.7 & \\
\hline Rumex pictus & & & 16.7 & & \\
\hline Salsola kali & & & 16.7 & 46.2 & 50 \\
\hline Sarcocornia fruticosa & 100 & 33.3 & 5 & 7.7 & 50 \\
\hline Schismus barbatus & & & & & \\
\hline Senecio glaucus subsp. coronopifolius & & 33.3 & 33.3 & 61.5 & 50 \\
\hline Soncuhs oleraceous & & & & 7.7 & \\
\hline Tamarix nilotica & 100 & & 16.7 & & \\
\hline Zygophyllum aegyptium & & 66.7 & 5 & 100 & 50 \\
\hline
\end{tabular}

\section{Species diversity}

Species diversity of the recorded species along the study habitats of the Deltaic strip of the study area (Table 4) showed that vegetation group (D) was the most diverse, which had the highest number of species (17 species), species richness (4.8 species 
stand $^{-1}$ ), turn over (3.5), relative evenness (2.4) and relative concentration of dominance (8.2). On the other side, vegetation group (A) was the least diverse with the lowest number of species ( 2 species), species richness $\left(2.0\right.$ species $\left.s t a n d^{-1}\right)$, turn over (1.0), relative evenness (0.7) and relative concentration of dominance (2.0).

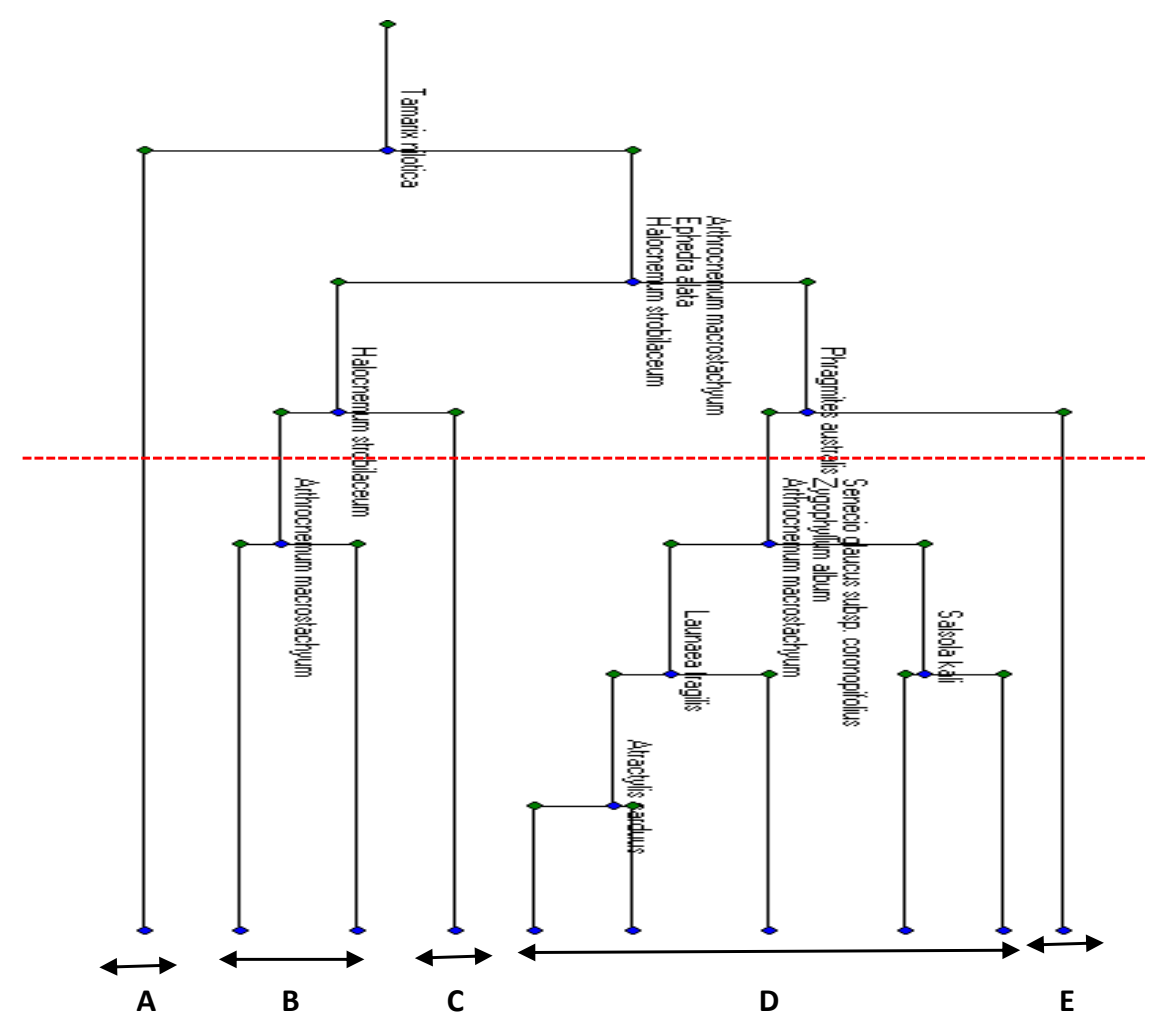

Figure 5. The dendrogram of the 5 vegetation groups produced from TWINSPAN classification

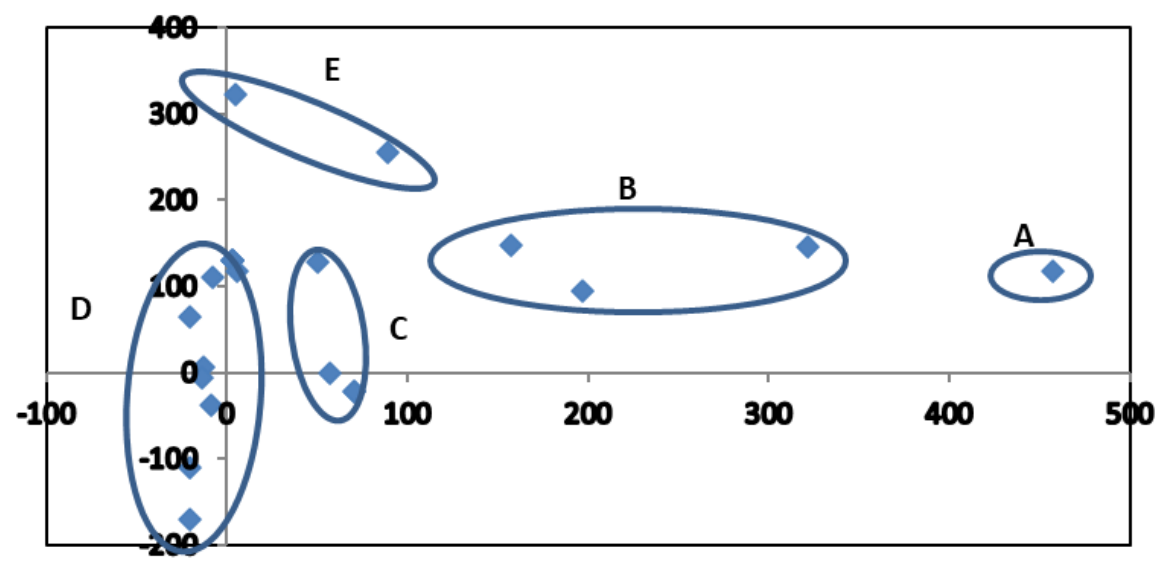

Figure 6. DCA-ordination of the 5 vegetation groups identified from TWINSPAN

\section{Discussion}

The study area comprised 32 species (21 perennials and 11 annuals) of vascular plants belonging to 14 families, while Galal and Fawzy (2007) recorded 69 species and Shaltout and Al-Sodany (2000) recorded 197 species in the sand dunes and Burullus 
wetland, respectively at Northern Nile Delta. This low number of species may be attributed to the smaller sampled area and the survey time. Zygophyllum aegyptium, which predominates the sand formations of the deltaic Mediterranean coast was recorded in the present study (Zahran and Willis, 2009) but was not recorded in the black sand dunes (Galal and Fawzy, 2007). Species composition of the study area varied markedly from that of the western Mediterranean coast, and this may be attributed to the difference in the climatic conditions and the soil chemical composition. Whereas the floristic taxa of the Western Mediterranean coastal belt were characterized with favourable climatic conditions compared with those of the other parts of Egypt (Zahran and Willis, 2009). Moreover, the number of species in the present study was lower figure than that recorded by Scholten et al. (1981), and Shaltout and Khalil (2005) on the Deltaic coast and this may be due to the smaller and less diverse habitats of the study area. Asteraceae, Chenopodiaceae, Brassicaceae, and poaceae, constituting most floristic elements of the study area, were in a harmony with Shehata and Galal (2015) in the Nile Delta, Galal et al. (2012) in the Northern Deltaic Lakes, Shalaby (1995) in Kafr El-Sheikh, Abd El-Fattah et al. (1992) in the fallow-lands of Zagazig city, and Mashaly (1987) in Dakahlia-Damietta coastal region.

Table 4. Diversity indices of the recorded species in the northern Nile Delta

\begin{tabular}{c|c|c|c|c|c|c}
\hline $\begin{array}{c}\text { Vegetation } \\
\text { group }\end{array}$ & $\begin{array}{c}\text { No. of } \\
\text { stands }\end{array}$ & $\begin{array}{c}\text { Total } \\
\text { species }\end{array}$ & $\begin{array}{c}\text { Species } \\
\text { richness }\end{array}$ & $\begin{array}{c}\text { Species } \\
\text { turnover }\end{array}$ & $\begin{array}{c}\text { Shannon } \\
\text { index }\end{array}$ & $\begin{array}{c}\text { Simpson } \\
\text { index }\end{array}$ \\
\hline A & $\underline{1}$ & $\underline{2}$ & $\underline{2.0}$ & $\underline{1.0}$ & $\underline{0.7}$ & $\underline{2.0}$ \\
B & 3 & 7 & 3.7 & 1.9 & 1.7 & 5.4 \\
C & 6 & 10 & 3.8 & 2.6 & 1.9 & 5.6 \\
D & $\underline{13}$ & $\underline{17}$ & $\underline{4.8}$ & $\underline{3.5}$ & $\underline{2.4}$ & $\underline{8.2}$ \\
E & 2 & 5 & 3.0 & 1.7 & 1.6 & 4.6 \\
\hline
\end{tabular}

Plant life forms are important in assessing the vegetation response to the environmental variations (Al-Yasi et al., 2019; Galal et al., 2021). The Mediterranean basin was considered a "therophyte climate" due to the high percentage of this life form in most Mediterranean floras (Raven, 1971). Therophytes were the dominant life forms, followed by chamaephytes, geophytes-helophytes, hemicryptophytes, phanerophytes, and parasites. Shehata and Galal (2015) and Heneidy and Bidak (2001) attributed the predominance of therophytes over the other life forms to the hyper-aridity, topography, and biotic effects in the study area. The chorology of the recorded species revealed the dominance of bi-regional taxa over the pluriregional, cosmopolitan and monoregional elements in accordance with Galal and Fawzy (2007) in their study on the sand dunes of the Deltaic coast. According to Hamed et al. (2018) and Alsherif (2019), the interregional species (bi-, tri- and pluri-regionals) dominated over mono-regionals, which may be due to the presence of interzonal variations, such as psammo-, halo- and hydrophilous habitats. According to the IUCN red data list, four recorded species (Ephedra alata, Silybum marianum, Juncus acutus and J. rigidus) were evaluated as least concern.

The classification of the vegetation of the study area by TWINSPAN led to identify 5 vegetation groups, which were separated along the DCA ordination axes reflecting moisture gradient. These vegetation groups inhabited the different habitats of the study area along moisture and salinity gradients. Similar results were reported by Galal and 
Fawzy (2007) and Shaltout and Khalil (2005) on the northern Mediterranean Coast. In addition, the recorded communities are mostly related to the communities described by Zahran et al. (1990) on the Mediterranean deltaic coast. The diversity of plant communities generated from multivariate analysis indicated that the communities that represent the sand bar are more diverse than the other communities, and this may be attributed to the high number of species transferred by the wind action (Zahran et al., 1990). In addition, the high plant diversity of such habitat is related to the increase in annuals during spring as reported by El-Kady et al. (2000) and Galal and Fawzy (2007).

\section{Conclusion}

Thirty-two species were recorded in the different habitats in the area under investigation. All recorded species are common in the different habitats along the Mediterranean coast. The vegetation of the study area is characterized by lower number of species compared with the number of the same habitats along the Mediterranean coast. The salt marsh habitat had the highest species diversity, while the tidal flats had the lowest. The common plant communities are: Arthrocnemum macrostachyum, Sarcocornia fruticosa and Halocnemum strobilaceum are dominant in salt marshes; Ephedra alata, Zygophyllum aegyptium, Senecio glaucus subsp. coronopifolius and Salsola kali are dominant in sand bar and sand formations. Twenty-seven species have medicinal, 26 grazing, 9 fuel and 8 human food uses. On the other hand, 16 species are sand controller and 11 are ruderals. Further study on the effect of environmental factors on the vegetation was required.

Acknowledgements. The authors are grateful to Taif University Researchers Supporting Project number (TURSP-2020/199), Taif University, Taif, Saudi Arabia for the financial support given to this research. They also wish to thank Mr. Yaser Sherif and Mr. Anwar Sarwat work at Environix for their kind help in the present work.

\section{REFERENCES}

[1] Abd El-Fattah, R. I., El-Hady, A. F., Baraka, D. M. (1992): On the ecology of wasteland of Zagazig area-Egypt. - Faculty of Education Journal, Ain Shams University 17: 565578.

[2] Abu Al-Izz, M. S. (1971): Landforms of Egypt. Translated by Dr Y. A. Fayid. American Univ. Cairo Press, Cairo.

[3] Alsherif, E. A. (2019): Ecological studies of Commiphora genus (myrrha) in Makkah Region, Saudi Arabia. - Heliyon 5: e01615.

[4] Al-Yasi, H. M., Alotaibi, S. S., Al-Sodany, Y. M., Galal, T. M. (2019): Plant distribution and diversity along altitudinal gradient of Sarrawat Mountains at Taif Province, Saudi Arabia. - Bioscience Research 16(2): 1198-1213.

[5] Appelgren, K., Mattila, J. (2005): Variation in vegetation communities in shallow bays of the northern Baltic Sea. - Aquatic Botany 83(1): 1-13.

[6] Belal, A. E., Springuel, I. (1996): Economic value of plant diversity in arid environments. - Natural Resource 32: 33-39.

[7] Boulos, L. (1983): Medicinal Plants of North Africa. - Reference Publications, Algonac, MI.

[8] Boulos, L. (1989): Geothermal development of Hammam Faraum hot spring. - SinaiEgypt, International Conference on Applications of Solar and Renewable Energy. 
[9] Boulos, L. (1999): Flora of Egypt, Vol. I (Azollaceae - Oxalidaceae). - Al Hadara Publ., Cairo.

[10] Boulos, L. (2000): Flora of Egypt. Vol. II. Geraniaceae-Boraginaceae. - Al Hadara Publ., Cairo.

[11] Boulos, L. (2002): Flora of Egypt. Vol. III. Verbinaceae-Compositae. - Al Hadara Publ., Cairo.

[12] Boulos, L. (2005): Flora of Egypt. Vol. IV. Monocotyledons (AlismataceaeOrchidaceae). - Al Hadara Publ., Cairo.

[13] Boulos, L. (2009): Flora of Egypt Checklist. - Al Hadara Publishing, Cairo.

[14] Danin, A. (1983): Desert Vegetation of Israel and Sinai. - Cana Publishing House, Jerusalem.

[15] El-Bayomi, G. M. (1999): Lake Burullus: a geomorphological study. - Ph. D. Thesis, Helwan University, Helwan, Egypt (in Arabic).

[16] El-Kady, H. F. (1980): Effect of grazing pressures and certain ecological parameters on some fodder plants of the Mediterranean coast of Egypt. - M.Sc. Thesis, Faculty of Science, Tanta University, Tanta.

[17] El-Kady, H. F., Shaltout, K. H., El-Shourbagy, M. N., Al-Sodany, Y. M. (2000): Characterization of Habitats in the North Western Part of the Nile Delta. - The First International Conference on Biological Sciences, Tanta Univ., Tanta, pp. 144-157.

[18] El-Sadek, L. M., Ayyad, M. (2000): Genetic Diversity as a Basic Component of Biodiversity: Case Studies in Egypt. - In: Nordenstam, B., El-Ghazaly, G., Kassas, N., Laurent, T. (eds.) Plant Systematics for the 21st Century. Portland Press, Maine, pp. 239250.

[19] Feinbrun-Dothan, N. (1978): Flora Palaestina. Part 3 (Ericaceae-Compositae). - The Israel Academy of Science and Humanities, Jerusalem Academic Press, Jerusalem.

[20] Feinbrun-Dothan, N. (1986): Flora Palaestina. Part 4 (Alismataceae-Orchidaceae). - The Israel Academy of Science and Humanities, Jerusalem Academic Press, Jerusalem.

[21] Galal, T. M. (2005): Flora and vegetation of north lakes of Egypt. - Ph. D. Thesis, Helwan University, Helwan.

[22] Galal, T. M., Fawzy, M. (2007): Sand dune vegetation in the coast of Nile Delta, Egypt. Global Journal Environment Research 1: 74-85.

[23] Galal, T. M., Shaltout, K. H., Hassan, L. M. (2012): The Egyptian Northern Lakes: Habitat Diversity, Vegetation and Economic Importance. - LAP Lambert Academic Publishing, Germany.

[24] Galal, T. M., Al-Yasi, H. M., Fadl, M. A. (2021): Vegetation zonation along the desertwetland ecosystem of Taif Highland, Saudi Arabia. - Saudi Journal of Biological Sciences (https://doi.org/10.1016/j.sjbs.2021.02.086).

[25] Hamed, M. A., Kasem, W. T., Shalabi, L. F. (2018): Floristic diversity and vegetationsoil correlations in Wadi Qusai, Jazan, Saudi Arabia. - International Journal of Plant and Soil Sciences 25(2): 1-18.

[26] Heneidy, S. Z., Bidak, L. M. (2001): Multipurpose plant species in Bisha, Asir region, southwestern Saudi Arabia. - Journal of King Saud University 13: 11-26.

[27] Hill, M. O. (1979a). DECORANA: A FORTRAN Program for Detrended Correspondence Analysis and Reciprocal Averaging. - Cornell Univ., Ithaca, NY.

[28] Hill, M. O. (1979b). TWINSPAN: A FORTRAN Program for Arranging Multivariate Data in an Ordered Two-Way Table by Classification of the Individual and Attributes. Cornell Univ., Ithaca, NY.

[29] Imam, M., Kosinova, J. (1972): Studies on the weed flora of cultivated land in Egypt. 2. Weeds of rice fields. - Botanische Jahrbücher für Systematik 139-153.

[30] Jafari, M., Zare Chahouki, M. A., Tavili, A., Azamivand, H. (2003): Soil-vegetation relationships in Hoze-Soltan region of Qom Province, Iran. - Pakistan Journal of Nutrition 2(6): 329-34. 
[31] Kandi, B., Sahu, S. C., Dhal, N. K., Mohanty, R. C. (2011): Species diversity of vascular plants of Sunabeda wildlife sanctuary, Odisha, India. - New York Science Journal 4(3): $1-9$.

[32] Khedr, A. A. (1989): Ecological studies on Lake Manzala, Egypt. - M.Sc. Thesis, Fac. Sci., Mansoura Univ., Mansoura.

[33] Khedr, A. A. (1997): Aquatic macrophyte distribution in Lake Manzala, Egypt. International Journal of Salt Lake Research 5: 221-239.

[34] Khedr, A. A., El-Demerdash, M. A. (1997): Distribution of aquatic plants in relation to environmental factors in the Nile Delta. - Aquatic Botany 56: 75-86.

[35] Magurran, A. E. (1988): Ecological Diversity and Its Measurements. - Croom. Helm., London.

[36] Mashaly, I. A. (1987): Ecological and floristic studies of Dakahlia-Damietta region. Ph.D. Thesis, Fac. Sci., Mansoura Univ., Mansoura.

[37] Naveh, Z., Dan, J. (1973): The Human Degradation of Mediterranean Landscapes in Israel. - In: di Castri, F., Mooney, H. A. (eds). Mediterranean-Type Ecosystems: Origin and Structure. Springer-Verlag, Berlin, pp. 373-390.

[38] Raunkiaer, C. (1937): Plant Life Forms. - Clarendon, Oxford.

[39] Raven, P. (1971): Relationships between Mediterranean Floras. - In: Davis, P. H., Harper, P. C., Hedge, I. C. (eds.). Plant Life in Southwest Asia. Botanical Society of Edinburgh, Edinburgh, pp. 119-134.

[40] Scholten, M. E., Hukkelhoven, M. W., Ayyad, M. A., Werger, M. J. (1981): Vegetation analysis in the coastal dune ecosystem of the western Egyptian desert. - Folia Geobotany \& Phytotaxonomy Prague 16: 293-308.

[41] Serag, M. S. (1991): Studies on the Ecology and Control of aquatic and canal bank weeds of the Nile Delta, Egypt. - Ph.D. Thesis, Fac. Sci., Mansoura Univ., Mansoura.

[42] Shalaby, M. A. (1995): Studies on plant life at Kafr El-Sheikh Province, Egypt. - M.Sc. Thesis, Faculty Agriculture, Kafr El-Sheikh, Tanta University, Egypt.

[43] Shaltout, K. H. (1997): Current Situation of Flora and Vegetation of South-West Egypt. In: Abdel-Ghaffar A. S., Marei S. M., Gaber H. M. (eds.) Integrated Land Development of Southern Egypt: Available Resources and Alternative Options. ICDR, CDRI, Canada, pp. 199-241.

[44] Shaltout, K. H., Al-Sodany, Y. M. (2000): Phytoecology of Lake Burullus Site. - Med Wet Coast, Global Environmental Facility (GEF) \& EEAA, Cairo.

[45] Shaltout, K. H., Khalil, M. T. (2005): Lake Burullus: Burullus Protected Area. - Egyptian Environmental Affairs Agency (EEAA), Cairo.

[46] Shaltout, K. H., El-Kady, H. F., Al-Sodany, Y. M. (1995): Vegetation analysis of the Mediterranean region of the Nile Delta. - Vegetatio 116: 73-83.

[47] Shehata, H. S., Galal, T. M. (2015): Factors affecting the distribution and associated species of Malva parviflora in the Nile Delta, Egypt. - Weed Biology and Management 15(1): 42-52.

[48] Täckholm, V. (1974): Student's Flora of Egypt, ( $2^{\text {nd }}$ Ed.). - Cairo University Press, Cairo.

[49] UNESCO (1977): Map of the world distribution of arid regions. - MAB Technical Notes 7.

[50] Zahran, M. A., Willis, A. J. (2009): The Vegetation of Egypt. 2nd Ed. - Springer, Heidelberg.

[51] Zahran, M., El Demerdash, M., Mashaly, I. (1990): Vegetation types of the deltaic Mediterranean coast of Egypt and their environment. - Journal of Vegetation Science 1: 305-310.

[52] Zegeye, H., Teketay, D., Kelbessa, E. (2006): Diversity, regeneration status and socioeconomic importance of the vegetation in the island of Lake Ziway, south-central Ethiopia. - Flora 201: 483-98. 
[53] Zhang, F., Zhan, J. T. (2000): Research progress of numerical classification and ordination of vegetation in China. - Journal of Shanxi University (National Science Education) 23: 278-282.

[54] Zohary, M. (1966): Flora Palaestina: Part 1 (Equisetaceae - Moringaceae). - The Israel Academy of Science and Humanities, Israel Jerusalem Academic Press, Jerusalem.

[55] Zohary, M. (1972): Flora Palaestina: Part 2 (Platanaceae - Umbelliferae). - The Israel Academy of Science and Humanities, Israel Jerusalem Academic Press, Jerusalem. pp. 489.

[56] Zohary, M. (1973): Geobotanical Foundations of the Middle East. Vols. 1-2. - Gustav Fischer Verlag, Stuttgart. 